\title{
Dwa światy spółdzielni socjalnych w Polsce
}

\author{
Michał Sobczak* \\ Streszczenie: Spółdzielczość socjalna jest jednym z narzędzi polityki społecznej, które ma za zadanie przeciw- \\ działać wykluczeniu społecznemu. W zależności od oddalenia od rynku pracy realizowane jest to \\ na dwa sposoby, tj. ścieżkę założycielską lub pracowniczą. Celem artykułu jest przedstawienie cha- \\ rakterystyki występujących w przestrzeni społeczno-gospodarczej dwóch typów spółdzielców \\ socjalnych, czyli właśnie założycieli i pracowników najemnych. Zwrócona też będzie szczególna \\ uwaga na różnice w sposobie realizacji przez spółdzielnie socjalne reintegracji zawodowej dla obu \\ typów spółdzielców wraz z analizą szans na powodzenie tego procesu. Rozważania w artykule \\ przeprowadzone zostały w oparciu o wyniki ankietowych badań własnych autora nad spółdziel- \\ czością socjalną w województwie łódzkim. \\ Przeprowadzone badania wskazały, że założyciele to zazwyczaj osoby młode, dobrze wykształ- \\ cone, przedsiębiorcze oraz pełne zapału do pracy. Spółdzielnia socjalna to dla nich szansa na speł- \\ nienie marzeń i spróbowanie sił w działalności gospodarczej. Pracownicy natomiast to w więk- \\ szości osoby słabo wykształcone, o niewielkich możliwościach odnalezienia się na otwartym \\ rynku pracy. Dzięki spółdzielni pracują, co powoduje poprawę ich sytuacji materialnej, a przy \\ okazji nabywają cenne kompetencje, które w razie konieczności zmiany pracy mogą wykorzystać \\ u nowego pracodawcy.
}

Słowa kluczowe: spółdzielnia socjalna, wykluczenie społeczne, inkluzja społeczna, rynek pracy.

\section{Wprowadzenie}

Spółdzielnie socjalne to organizacje wprowadzone do polskiego porządku prawnego w celu rozszerzenia oferty organizacji zajmujących się inkluzją społeczną, czyli przeciwdziałaniu wykluczeniu społecznemu. Organizacje te działają poprzez prowadzenie reintegracji zawodowej i społecznej osób w nich zatrudnionych, które to procesy odbywają się niejako przy okazji świadczenia pracy dla spółdzielni.

Spółdzielczość socjalna oferuje dwie możliwe ścieżki reintegracji społeczno-zawodowej. Pierwsza - założycielska - dotyczy spółdzielni socjalnych założonych przez osoby fizyczne i częściej obierana jest przez osoby samodzielne, przedsiębiorcze, dość dobrze wykształcone, dla których spółdzielnia może być sposobem na przezwyciężenie chwilowych problemów życiowych. Druga - pracownicza - związana jest głównie ze spółdzielniami socjalnymi zakładanymi przez osoby prawne. Tu spotkamy najczęściej osoby zdecydowanie bardziej oddalone od otwartego rynku pracy, które dopatruja się w spółdzielni jednej z ostatnich szans na jakąś poprawę ich sytuacji życiowej.

Celem artykułu jest przedstawienie charakterystyki występujących $\mathrm{w}$ przestrzeni społeczno-gospodarczej dwóch typów spółdzielców socjalnych: założycieli i pracowników najemnych. Zwrócona też będzie szcze-

\section{* Michał Sobczak}

Katedra Pracy i Polityki Społecznej Wydział Ekonomiczno-Socjologiczny Uniwersytet Łódzki

ul. Rewolucji 1905 r. nr 39, 90-214 Łódź e-mail:msobczak@uni.lodz.pl 
gólna uwaga na różnice w sposobie realizacji przez spółdzielnie socjalne reintegracji zawodowej dla obu typów spółdzielców wraz $z$ analizą szans na powodzenie tego procesu. Rozważania w artykule przeprowadzone zostały w oparciu o wyniki badań własnych autora nad spółdzielczością socjalną w województwie łódzkim.

W pierwszej części artykułu przeprowadzono od strony prawnej analizę wyodrębnienia się dwóch typów spółdzielców socjalnych w Polsce. Następnie opisano od strony teoretycznej przebieg procesu inkluzji społecznej w spółdzielniach socjalnych. W ostatniej części artykułu przedstawiono wyniki badań własnych, które obrazują różnice pomiędzy założycielami a pracownikami najemnymi spółdzielni socjalnych w Polsce.

\section{Jak powstały dwa typy spółdzielni socjalnych w Polsce}

Spółdzielczość socjalna pojawiła się $\mathrm{w}$ polskim porządku prawnym $\mathrm{w}$ ustawie $\mathrm{z}$ dnia 20 kwietnia 2004 roku o promocji zatrudnienia i instytucjach rynku pracy (Dz.U. $2004 \mathrm{nr}$ 99 poz. 1001), którą to znowelizowano Prawo spółdzielcze, dopisując do niego zasady tworzenia i funkcjonowania spółdzielni socjalnych. Na mocy tych przepisów zaczęły powstawać pierwsze tego typu organizacje, jednak bez dedykowanych programów wsparcia rozwój tej branży spółdzielczej był bardzo wolny. Dwa lata później przyjęto ustawę z dnia 27 kwietnia 2006 roku o spółdzielniach socjalnych (Dz.U. 2006 nr 94 poz. 651), która z uwzględnieniem kilku nowelizacji reguluje spółdzielczość socjalną w Polsce do chwili obecnej. Rozwiązania zastosowane w naszym kraju oparto o doświadczenia włoskie [Brzozowska, 2011, s. 227-229].

Zgodnie z zapisami wyżej przytoczonych aktów prawnych przedmiotem działalności spółdzielni socjalnej jest prowadzenie wspólnego przedsiębiorstwa w oparciu o osobistą pracę członków organizacji. Celem aktywno- ści ekonomicznej w spółdzielni socjalnej jest jednak społeczno-zawodowa reintegracja zatrudnionych, którzy w większości powinni się wywodzić z grup zagrożonych wykluczeniem społecznym. Można powiedzieć, że spółdzielnie socjalne wypełniły lukę pomiędzy organizacjami prowadzącymi wstępne działania $z$ zakresu reintegracji społeczno-zawodowej wykluczonych, jak kluby lub centra integracji społecznej, a otwartym rynkiem pracy [Koperek, Koperek, 2015, s. 14-19].

W pierwotnym rozwiązaniu organizacyjno-prawnym spółdzielnie socjalne mogły być zakładane tylko przez osoby fizyczne, a minimum $80 \%$ z nich musiały stanowić osoby zagrożone wykluczeniem społecznym. Bardzo szybko okazało się, że niewiele osób, u których faktycznie nagromadziły się problemy życiowe, potrafiło skutecznie prowadzić tego typu przedsiębiorstwo. Spółdzielcom najzwyczajniej brakowało kompetencji, doświadczenia i wiedzy fachowej. W tamtym okresie w spółdzielczości socjalnej najlepiej radzili sobie bezrobotni absolwenci szkół wyższych, którzy chcieli spróbować sił w biznesie, nie ryzykując zbyt wielu własnych środków. Stąd pierwsza nowelizacja ustawy o spółdzielniach socjalnych z 2009 roku (Dz.U. 2009 nr 91 poz. 742) obniżyła wymóg 80\% zagrożonych wykluczeniem społecznym do co najmniej połowy. Ponadto, wprowadzono możliwość zakładania spółdzielni socjalnych przez osoby prawne (co najmniej dwie), takie jak organizacje pozarządowe, kościelne osoby prawne czy jednostki samorządu terytorialnego. W takim przypadku spółdzielnia socjalna ma obowiązek zatrudnić co najmniej połowę pracowników z grup zagrożonych wykluczeniem społecznym. Było to wyjście naprzeciw postulatom, które pojawiały się po pierwszym okresie powstawania spółdzielni socjalnych w Polsce. Samodzielne utworzenie przedsiębiorstwa przez osoby w bardzo trudnej sytuacji zawodowej i życiowej najczęściej kończyło się niepowodzeniem przedsięwzięcia, co poddawało w wątpliwość sensowność 
wspierania spółdzielczości socjalnej w Polsce. Sukces odnosiły głównie projekty osób, które raczej przejściowo znalazły się w trudniejszym położeniu. Dla osób w bardzo trudnej sytuacji życiowej i zawodowej ważne jest, aby trafić do bezpiecznego, dobrze zorganizowanego miejsca pracy, stąd dla nich lepsze powinny być spółdzielnie socjalne osób prawnych [Szczygieł, 2014, s. 45-46].

W ten właśnie sposób powstały w Polsce dwa typy spółdzielni socjalnych, potocznie nazywane spółdzielniami „osób fizycznych" oraz „osób prawnych”. Jak się okazało, przy okazji wytworzyły się również dwa typy spółdzielców socjalnych w Polsce:

- założyciele spółdzielni to osoby, które miały okazję współtworzyć spółdzielnię socjalną osób fizycznych. Charakteryzują się oni dość dużą samodzielnością życiową i przedsiębiorczością. Decyzja o założeniu spółdzielni była dla nich jednym ze sposobów na rozwiązanie raczej przejściowych problemów życiowych;

- pracownicy najemni spółdzielni to osoby zatrudnione w zdecydowanej większości w spółdzielniach socjalnych osób prawnych. Przystępowali oni do istniejących organizacji jako pracownicy najemni i sporadycznie zostają członkami organizacji. Charakteryzują się małą samodzielnością życiową, ich powrót na otwarty rynek pracy wydaje się być bardzo trudny [Sobczak, 2015, s. 176-177].

Podział na te dwa typy spółdzielców socjalnych wytworzył się niejako samoczynnie, wraz z możliwością zakładania spółdzielni przez osoby prawne, jednak znalazł też swoje usankcjonowanie w polityce rynku pracy wraz z wprowadzeniem profilowania bezrobotnych [Wojdyło-Preisner, 2009, 49-56]. Ustawa z dnia 14 marca 2014 roku o zmianie ustawy o promocji zatrudnienia i instytucjach rynku pracy oraz niektórych innych ustaw (Dz. U. 2014 poz. 598) wprowadziła w Polsce trzy profile bezrobotnych. Mają one za zadanie określić stopień oddalenia bezrobotnego od otwartego rynku pracy. Profil I przeznaczony jest dla aktywnych bezrobotnych, czyli osób potrzebujących właściwie tylko oferty pracy lub stosunkowo niewielkiego wsparcia w dostosowaniu się do aktualnych wymogów. Jedną z proponowanych form pomocy w tym przypadku jest uruchomienie spółdzielni socjalnej. Pozostałe dwa profile przeznaczone są dla bezrobotnych znacznie bardziej oddalonych od otwartego rynku pracy, a jedną z proponowanych form pomocy jest podjęcie pracy w spółdzielni socjalnej osób prawnych [Łukasiewicz, 2016, s. 224-226].

\section{Przebieg inkluzji społecznej w spółdzielniach socjalnych}

Do prowadzenia inkluzji społecznej w Polsce wykorzystywanych jest wiele różnych podmiotów ekonomii społecznej. Można tu wskazać szczególnie na: Kluby Integracji Społecznej (KIS), Centra Integracji Społecznej (CIS), Warsztaty Terapii Zajęciowej (WTZ), Zakłady Aktywności Zawodowej (ZAZ) i spółdzielnie socjalne, ale również wyspecjalizowane stowarzyszenia, fundacje, spółki non-profit, czy spółdzielnie pracy i inwalidów. Modelowa reintegracja przebiega według schematu przedstawionego na rysunku 1.

Zgodnie z powyższym schematem, do Klubów Integracji Społecznej trafiają raczej klienci skierowani z instytucji publicznych, np. urzędów pracy lub organizacji pozarządowych, czy po prostu przypadkowe osoby szukające wsparcia. Następnie KIS-y, a w dalszej kolejności CIS-y przeprowadzają wstępną reintegrację zawodową i przekazują tych klientów dalej, czyli np. zachęcają ich do przystąpienia, bądź założenia spółdzielni socjalnej albo oferują inną formę zatrudnienia socjalnego. Celem tego procesu jest wprowadzenie osób zagrożonych ekskluzją społeczną na otwarty rynek pracy [Sobczak, 2016b, s. 120-121]

Już sam fakt oferowania pracy osobom zagrożonym wykluczeniem społecznym 
powoduje, że osoby pracujące w spółdzielniach socjalnych przechodzą proces reintegracji społeczno-zawodowej. Dodatkowo, konkurowanie $w$ warunkach rynkowych wymusza na spółdzielcach ciągła profesjonalizację, poprawę jakości świadczonych usług i oferowanych produktów oraz coraz sprawniejszą obsługę klientów. Spółdzielnia socjalna pozwala zatem zatrudnionym na uzupełnienie oraz podniesienie kwalifikacji zawodowych, a nawet na zupełną reorientację zawodową [Sobol, 2009, s. 33].

\section{Rysunek 1. System reintegracji zawodowej w Polsce oparty o podmioty ekonomii} społecznej

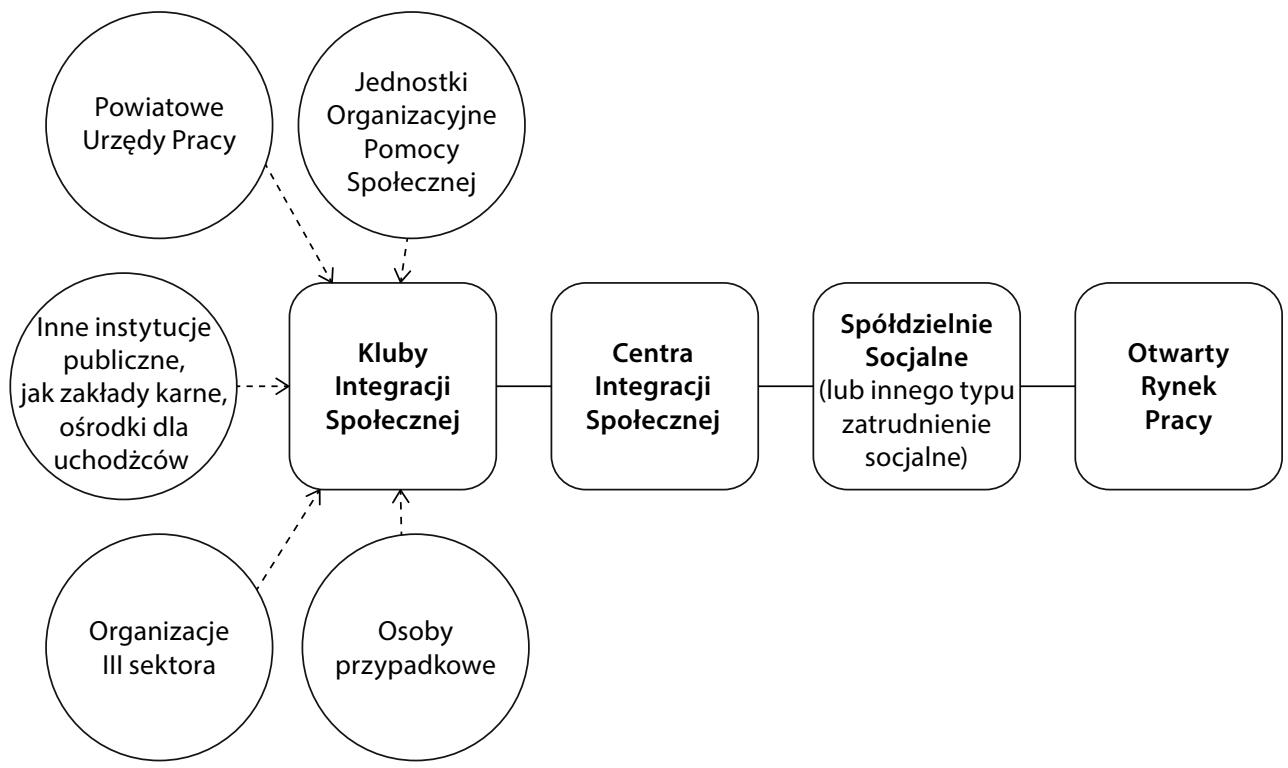

Źródło: [Sobczak, 2016b, s. 121].

Reintegracja społeczna w spółdzielniach socjalnych przebiega równolegle do reintegracji zawodowej. Jej przebieg jest związany nierozerwalnie z pracą w grupie, która tworzy spółdzielnię. Właśnie praca grupowa powoduje, że [Kliombka-Jarzyna, 2009, s. 32-34]:

1. Członkowie spółdzielni socjalnych czują się bezpieczniej, są bardziej pewni siebie, mniej wątpią we własne możliwości. Dzięki pracy w grupie są bardziej odporni na zagrożenia płynące z zewnątrz.

2. Członkowie spółdzielni socjalnych czują się ważni i wyróżnieni, a inni traktują ich z poważaniem, bo zdobyli się na odwagę i determinację, by taką organizację założyć.
3. Dzięki uznaniu ze strony innych wzrasta samoocena spółdzielców socjalnych i ich wiara we własne możliwości.

4. Spółdzielnia socjalna zaspokaja potrzebę przynależności - członkowie czują się potrzebni, użyteczni, należą do określonej komórki społecznej.

5. Członkowie spółdzielni czerpią z grupy siłę do realizacji zadań, których zapewne nie podjęliby się w pojedynkę.

6. Do wykonania niektórych zadań potrzebna jest kombinacja umiejętności i wiedzy różnych osób, więc grupa staje się niezbędna do ich realizacji.

7. Działając w grupie zmniejsza się ryzyko popełnienia błędu. 
8. Działalność grupowa skutkuje wyższym poziomem kapitału społecznego w porównaniu do przedsiębiorcy działającego w pojedynkę.

9. Grupa pobudza kreatywność i motywuje do bardziej efektywnego działania wszystkich jej członków.

10. Działając w grupie spółdzielcy zyskują nowych przyjaciół i utrwalają dawne przyjaźnie.

11. Pracując w grupie członkowie wiele uczą się od innych i od siebie nawzajem.

12. Członkowie grupy udzielają sobie wsparcia w trudnych chwilach - pokazują, że warto działać pomimo pojawiających się trudności.

13. Praca w grupie uczy, jak rozwiązywać konflikty, komunikować się z innymi oraz jak panować nad wybuchami złości. To, co powstrzymuje członków spółdzielni od niewłaściwych zachowań to poczucie wstydu, odczuwane przed innymi członkami grupy.

14. Spółdzielnie socjalne uczą demokracji dzięki takiemu właśnie systemowi podejmowania decyzji.

Większość z wyżej wymienionych korzyści to kompetencje cenione i poszukiwane przez pracodawców na otwartym rynku pracy, co oznacza, że osoby zatrudnione w spółdzielniach socjalnych podnoszą swoją zdolność do konkurowania w ramach rynku pracy. Niewątpliwie patrząc na spółdzielnie socjalne z tego punktu widzenia można stwierdzić, że wpisują się one w koncepcję przejściowych rynków pracy (Transitional Labour Markets), gdzie trafiają ludzie niezdolni do podjęcia zatrudnienia na rynkach otwartych. Z założenia osoby trafiające na przejściowy rynek pracy powinny uniezależnić się od pomocy społecznej i przygotować do ponownego konkurowania w ramach rynku otwartego [Schmid, 1998, s. 5-10].

Odnosząc się do wyróżnionych wcześniej dwóch typów spółdzielców socjalnych można stwierdzić, że proces reintegracji spo- łeczno-zawodowej przebiega lepiej wśród założycieli, którzy byli po prostu mniej oddaleni od otwartego rynku pracy. Spółdzielczość socjalna to dla nich szansa na usamodzielnienie się oraz na wzięcie we własne ręce odpowiedzialności za swoje życie i pracę. Niezależnie od rodzaju wykonywanej pracy na rzecz organizacji, uzyskują dodatkowo poczucie sprawstwa. Mają szanse rozwinąć wiele kompetencji związanych z prowadzeniem biznesu i pracą w zespole. W przypadku pracowników istotne jest to, że wracają oni na rynek pracy. Uczą się obowiązkowości, zyskują poczucie przydatności oraz rozwijają szereg kompetencji ściśle powiązanych ze stanowiskiem pracy. Z punktu widzenia interesu społecznego prowadzenie reintegracji zawodowej w obu tych grupach jest zatem równie ważne.

Z punktu widzenia interesu publicznego istotne jest też, że reintegracja zawodowa w spółdzielniach socjalnych może być uznana za efektywną finansowo i środowiskowo. Organizacje te generują przychody i ponoszą wydatki, co obniża konieczność wsparcia ze środków publicznych procesu aktywizowania osób bezrobotnych. Praca spółdzielców pozwala też na osiągnięcie założonych celów aktywizacji zawodowej i doprowadzenie do samodzielności ekonomicznej [Sobczak, 2016a, s. 47-48].

Spółdzielczość socjalna to instrument aktywizacji społeczno-zawodowej osób wykluczonych, który zdaje się być dotąd nie w pełni wykorzystywany. Klienci spółdzielni socjalnych, szczególnie ci zaliczani do grupy pracowników, zdają się być największym wyzwaniem dla publicznych służb zatrudnienia, gdyż dla tych osób brakuje ofert nawet, gdy mamy do czynienia z dobrą sytuacją na rynku pracy. Wynika to z niedopasowania ich kompetencji do wymagań rynkowych. Podjęcie mimo wszystko trudu aktywizacji tych osób przynosi jednak szereg korzyści dla:

- samorządu - mniej podopiecznych ośrodków pomocy społecznej, więcej ludzi 
aktywnych zawodowo, a zatem mniejsze wydatki socjalne,

- służb zatrudnienia - odciążenie od najtrudniejszej klienteli, która odnajduje swoje miejsce w spółdzielniach socjalnych,

- społeczności lokalnych - więcej firm świadczących usługi ważne dla rozwoju lokalnego (np. usługi opiekuńcze na terenach mało zurbanizowanych).

Zatem spółdzielnie socjalne są organizacjami, w których rozwój warto inwestować, a ich działalność winna być szeroko promowana oraz dobrze rozumiana przez władze lokalne i urzędników związanych z polityką społeczną [Koral, 2008, s. 2].

\section{Dwa typy spółdzielców socjalnych w badaniach}

Ta część artykułu została oparta na wynikach badań ankietowych prowadzonych z założycielami oraz pracownikami najemnymi z 42 spółdzielni socjalnych z regionu łódzkiego w okresie od grudnia 2013 do czerwca 2014 r. Badania zostały wykonane przez ankieterów bezpośrednio w spółdzielniach. Użyte na potrzeby niniejszego artykułu badania były częścią większego projektu badawczego związanego z badaniem skuteczności spółdzielczości socjalnej w zakresie reintegracji zawodowej osób zagrożonych ekskluzją społeczną w Polsce na przykładzie województwa łódzkiego. Podjęta została próba bezpośredniego dotarcia do wszystkich 82 spółdzielni socjalnych zarejestrowanych w regionie na koniec listopada 2013 r. W ramach tego projektu przeprowadzono też badanie ankietowe skierowane do zarządów spółdzielni, co pozwoliło przeanalizować spółdzielnie jako przedsiębiorstwa. Przeprowadzono także wywiady z przedstawicielami podmiotów z otoczenia spółdzielni socjalnych, takich jak: ośrodki wsparcia ekonomii społecznej, urzędy oraz Ogólnopolski Związek Rewizyjny Spółdzielni Socjalnych. Analiza w niniejszym artykule została oparta wprawdzie tylko na jednym komponencie badawczym, jednak wyciągane przez autora wnioski wynikają również siłą rzeczy ze znajomości szerszych wyników badań.

Obie grupy spółdzielców socjalnych różnią się od siebie znacznie już na poziomie charakterystyki próby. Szczegółowe dane na ten temat przedstawia tabela 1. Próba badawcza składała się z 74 pracowników najemnych oraz 116 założycieli spółdzielni. Taką też przyjęto liczebność próby przy analizie odpowiedzi na pytania wielokrotnego wyboru. Jednak nie wszyscy respondenci odpowiadali na każde pytanie, co przełożyło się na przyjęte liczebności próby w pytaniach jednokrotnego wyboru - wtedy tabela zawiera odpowiednią wartość N lub ogółem, które sugerują właściwą liczebność próby.

Tabela 1. Struktura próby pracowników najemnych i założycieli spółdzielni socjalnych wg płci, wieku, miejsca zamieszkania, poziomu wykształcenia i stanu cywilnego

\begin{tabular}{|l|c|c|c|c|c|c|}
\hline \multirow{2}{*}{ Kategoria } & \multicolumn{2}{|c|}{ Założyciele spółdzielni } & \multicolumn{2}{c|}{ Pracownicy najemni } & \multicolumn{2}{c|}{ 0gółem } \\
\cline { 2 - 8 } & I. osób & {$[\%]$} & I. osób & {$[\%]$} & I. osób & [\%] \\
\hline \multirow{2}{*}{ PŁEĆ } & \multicolumn{2}{|c|}{$\mathrm{N}=114$} & \multicolumn{2}{|c|}{$\mathrm{N}=70$} & \multicolumn{2}{c|}{$\mathrm{N}=184$} \\
\hline Kobieta & 69 & 60,5 & 30 & 42,9 & 99 & 53,8 \\
\hline Mężczyzna & 45 & 39,5 & 40 & 57,1 & 85 & 46,2 \\
\hline \multicolumn{1}{|c|}{ WIEK } & \multicolumn{2}{|c|}{$\mathrm{N}=115$} & \multicolumn{2}{|c|}{$\mathrm{N}=72$} & \multicolumn{2}{c|}{$\mathrm{N}=187$} \\
\hline Do 34 lat & 64 & 55,7 & 33 & 45,8 & 97 & 51,9 \\
\hline 35-54 lata & 35 & 30,4 & 25 & 34,7 & 60 & 32,1 \\
\hline Powyżej54 lat & 16 & 13,9 & 14 & 19,4 & 30 & 16,0 \\
\hline
\end{tabular}




\begin{tabular}{|c|c|c|c|c|c|c|}
\hline \multirow{2}{*}{ Kategoria } & \multicolumn{2}{|c|}{ Założyciele spółdzielni } & \multicolumn{2}{|c|}{ Pracownicy najemni } & \multicolumn{2}{|c|}{ Ogółem } \\
\hline & I. osób & [\%] & I. osób & [\%] & I. osób & [\%] \\
\hline WYKSZTAŁCENIE & \multicolumn{2}{|c|}{$N=114$} & \multicolumn{2}{|c|}{$\mathrm{N}=71$} & \multicolumn{2}{|c|}{$\mathrm{N}=185$} \\
\hline Co najwyżej podstawowe & 2 & 1,8 & 19 & 26,8 & 21 & 11,4 \\
\hline Gimnazjalne & 6 & 5,3 & 5 & 7,0 & 11 & 5,9 \\
\hline Średnie, zawodowe & 49 & 43,0 & 31 & 43,7 & 80 & 43,2 \\
\hline Wyższe & 57 & 50,0 & 16 & 22,5 & 73 & 39,5 \\
\hline MIEJSCE ZAMIESZKANIA & \multicolumn{2}{|c|}{$N=114$} & \multicolumn{2}{|c|}{$\mathrm{N}=71$} & \multicolumn{2}{|c|}{$N=185$} \\
\hline Wieś & 23 & 20,2 & - & - & 23 & 12,4 \\
\hline Miasto & 91 & 79,8 & 71 & 100,0 & 162 & 87,6 \\
\hline STAN CYWILNY & \multicolumn{2}{|c|}{$N=116$} & \multicolumn{2}{|c|}{$\mathrm{N}=74$} & \multicolumn{2}{|c|}{$\mathrm{N}=190$} \\
\hline Mężatkal żonaty & 48 & 42,5 & 20 & 27,8 & 68 & 36,8 \\
\hline W związku nieformalnym & 19 & 16,8 & 9 & 12,5 & 28 & 15,1 \\
\hline Pannal kawaler & 34 & 30,1 & 24 & 33,3 & 58 & 31,4 \\
\hline Po rozwodzie & 11 & 9,7 & 10 & 13,9 & 21 & 11,4 \\
\hline Wdowal wdowiec & 1 & 0,9 & 9 & 12,5 & 10 & 5,4 \\
\hline
\end{tabular}

Źródło: [Sobczak, 2016a, s. 102].

Z powyższych danych wyłania się obraz założyciela spółdzielni jako młodej kobiety, z dobrym wykształceniem, najczęściej mieszkającej w mieście, o ułożonym życiu prywatnym. W przypadku pracowników spółdzielni są to raczej młodzi mężczyźni, dość słabo wykształceni, pochodzący tylko z miast, częściej stanu wolnego. Te dwie populacje różnią się również pod względem czasu poświęcanego na pracę tygodniowo (tabela 2).

Tabela 2. Faktycznie przepracowywana średniotygodniowa liczba godzin pracy przez pracowników i założycieli badanych spółdzielni socjalnych

\begin{tabular}{|l|c|c|c|c|c|c|}
\hline \multirow{2}{*}{ Tygodniowy czas pracy w h } & \multicolumn{2}{|c|}{ Założyciele spółdzielni } & \multicolumn{2}{c|}{ Pracownicy najemni } & \multicolumn{2}{c|}{ Ogółem } \\
\cline { 2 - 7 } & I. osób & {$[\%]$} & I. osób & {$[\%]$} & I. osób & {$[\%]$} \\
\hline Poniżej 20 & 22 & 21,2 & 12 & 18,2 & 34 & 20,0 \\
\hline $20-39$ & 19 & 18,3 & 8 & 12,1 & 27 & 15,9 \\
\hline 40 & 21 & 20,2 & 36 & 54,5 & 57 & 33,5 \\
\hline $41-60$ & 28 & 26,9 & 10 & 15,2 & 38 & 22,4 \\
\hline Powyżej 60 & 14 & 13,5 & - & - & 14 & 8,2 \\
\hline OGÓłEM & 104 & 100,0 & 66 & 100,0 & 170 & 100,0 \\
\hline
\end{tabular}

Źródło: [Sobczak, 2016a, s. 105].

Duża grupa założycieli spółdzielni socjalnych miała wspólną cechę z osobami prowadzącymi działalność gospodarczą potrafili poświęcać na pracę więcej godzin tygodniowo niż wynosi pełny wymiar czasu pracy, czyli 41 h i więcej. W wielu organizacjach napotkano nawet założycieli zatrudnionych na część etatu (np. 1/16), a faktycznie pracujących nawet $100 \mathrm{~h}$ w tygodniu. Natomiast u pracowników najemnych przepra- 
cowana średniotygodniowa liczba godzin wynosiła dla 54,5\% badanych równo $40 \mathrm{~h}$, a $30 \%$ pracowało na ogół krócej. Warto tu dodać, że pracownicy spółdzielni socjalnych też zdecydowanie lepiej zarabiają (choć niewiele więcej od płacy minimalnej), dla nich zarobkowy wymiar tej pracy ma jednak duże znaczenie. Założyciele raczej zarabiali mniej, a z rozmów z nimi wynikało, że oczekiwali lepszych wynagrodzeń w przyszłości, gdy przedsiębiorstwo się rozwinie.

Istotne dla niniejszych rozważań są również czynniki, które miały wpływ na decyzję o założeniu lub przystąpieniu do spółdzielni socjalnej. W obu badanych grupach do najważniejszych czynników należały: możliwość uzyskania dochodów (założyciele - 50\%, pracownicy - 58,1\%) oraz chęć zdobycia pracy (odpowiednio: 49,1\% oraz 55,4\%). U założycieli do najważniejszych czynników należy również wewnętrzna chęć dokonania zmiany w życiu (49,1\%), która wśród pracowników była wymieniana przez mniej niż $1 / 3$ respondentów. Do istotnych różnic zaliczyć też można to, że dla 1/3 założycieli spółdzielni wpływ na jej założenie miała chęć spróbowania sił w biznesie, a dla 1/5 namowa znajomych. Wynikać to mogło z tego, że dla sporej grupy założycieli spółdzielnia socjalna była szansą na utworzenie swojego wymarzonego biznesu, a do rozpoczęcia działalności w tej formie prawnej potrzeba kilku osób, stąd poszukiwania chętnych odbywały się często wśród znajomych. Pracownicy natomiast częściej wymieniali namowę rodziny oraz pracownika socjalnego, co można interpretować jako przejaw mniejszej samodzielności tych osób. Dość duże różnice pomiędzy tymi grupami widać też porównując najważniejsze oczekiwane korzyści z pracy w spółdzielniach socjalnych (tabela 3).

Dla pracowników najważniejszą z oczekiwanych korzyści z pracy w spółdzielni było uzyskiwanie dochodów, o wiele ważniejszą niż w przypadku założycieli, o czym świadczy istotność statystyczna tej różnicy. Dla założycieli była to oczywiście dość ważna korzyść, jednak minimalnie więcej respondentów wskazało na nowe kwalifikacje zawodowe (istotnie statystycznie więcej niż wśród pracowników). Pozostałe korzyści znacznie częściej wskazywane w grupie założycieli niż pracowników to zdobywanie kontaktów zawodowych i realizacja własnych marzeń. Dość jasno wskazuje to, że problemy ekonomiczne dla założycieli nie były głównym motywatorem do założenia spółdzielni.

Tabela 3. Najważniejsze korzyści ekonomiczne i zawodowe z pracy w spółdzielniach socjalnych według oczekiwań pracowników i założycieli

\begin{tabular}{|c|c|c|c|c|}
\hline \multirow{2}{*}{$\begin{array}{l}\text { Najważniejsze oczekiwane korzyści z pracy } \\
\text { w spółdzielni socjalnej: }\end{array}$} & & \multicolumn{2}{|c|}{ Grupa } & \multirow[b]{2}{*}{ Ogółem [N = 190} \\
\hline & & $\begin{array}{c}\text { założyciele spółdzielni } \\
{[N=116]}\end{array}$ & $\begin{array}{c}\text { pracownicy spółdzielni } \\
{[\mathrm{N}=74]}\end{array}$ & \\
\hline \multicolumn{5}{|c|}{ KORZYŚCI EKONOMICZNE } \\
\hline \multirow{2}{*}{ uzyskanie dochodów } & $\mathrm{N}$ & 64 & 56 & 120 \\
\hline & $\%$ & 55,2 & 75,7 & 63,2 \\
\hline \multicolumn{5}{|c|}{$\mathrm{p}=0,004$, Phi $=-, 21$, Chi-kwadrat $=8,16(\mathrm{df}=1)$} \\
\hline \multirow{2}{*}{ niezależność } & $\mathrm{N}$ & 40 & 19 & 59 \\
\hline & $\%$ & 34,5 & 25,7 & 31,1 \\
\hline \multicolumn{5}{|c|}{$p=0,20$} \\
\hline
\end{tabular}




\begin{tabular}{|c|c|c|c|c|}
\hline \multirow{2}{*}{$\begin{array}{l}\text { Najważniejsze oczekiwane korzyści z pracy } \\
\text { w spółdzielni socjalnej: }\end{array}$} & & \multicolumn{2}{|c|}{ Grupa } & \multirow[b]{2}{*}{ Ogółem [N = 190] } \\
\hline & & $\begin{array}{l}\text { założyciele spółdzielni } \\
\qquad[\mathrm{N}=116]\end{array}$ & $\begin{array}{c}\text { pracownicy spółdzielni } \\
{[\mathrm{N}=74]}\end{array}$ & \\
\hline \multicolumn{5}{|c|}{ KORZYŚCIZAWODOWE } \\
\hline \multirow{2}{*}{ nowe kwalifikacje zawodowe } & $\mathrm{N}$ & 65 & 25 & 90 \\
\hline & $\%$ & 56,0 & 33,8 & 47,4 \\
\hline \multicolumn{5}{|c|}{$p=0,003$, Phi $=0,22$, Chi-kwadrat $=8,97(d f=1)$} \\
\hline \multirow{2}{*}{$\begin{array}{l}\text { kontakty, które będzie można w przyszłości } \\
\text { wykorzystać dla rozwoju zawodowego }\end{array}$} & $\mathrm{N}$ & 58 & 23 & 81 \\
\hline & $\%$ & 50,0 & 31,1 & 42,6 \\
\hline \multicolumn{5}{|c|}{$\mathrm{p}=0,01$, Phi $=0,19$, Chi-kwadrat $=6,61(\mathrm{df}=1)$} \\
\hline \multirow{2}{*}{ realizacja własnych marzeń } & $\mathrm{N}$ & 45 & 9 & 54 \\
\hline & $\%$ & 38,8 & 12,2 & 28,4 \\
\hline \multicolumn{5}{|c|}{$\mathrm{p}<0,001$, Phi $=0,29$, Chi-kwadrat $=15,75(\mathrm{df}=1)$} \\
\hline
\end{tabular}

Źródło: [Sobczak, 2016a, s. 115-116].

Jedną z klasycznych cech przedsiębiorstwa społecznego jest system podejmowania decyzji oparty na zasadach współuczest- nictwa, demokratyczny - jeden interesariusz jeden głos. Jak wygląda to w praktyce, obrazuje tabela 4.

\section{Tabela 4. Sposoby podejmowania decyzji w spółdzielniach socjalnych według pracowników najemnych i założycieli}

\begin{tabular}{|l|c|c|c|c|c|c|}
\hline \multirow{2}{*}{ Sposoby podejmowania decyzji w spółdzielniach socjalnych } & \multicolumn{2}{c|}{$\begin{array}{c}\text { Założyciele } \\
\text { spółdzielni }\end{array}$} & \multicolumn{2}{c|}{$\begin{array}{c}\text { Pracownicy } \\
\text { najemni }\end{array}$} & \multicolumn{2}{c|}{ 0gółem } \\
\cline { 2 - 10 } & I. osób & {$[\%]$} & I. osób & {$[\%]$} & I. osób & {$[\%]$} \\
\hline $\begin{array}{l}\text { Zdecydowana większość decyzji w spółdzielni była podejmowana } \\
\text { przez wszystkich członków, bądź przynajmniej z nimi konsultowana }\end{array}$ & 68 & 60,7 & 21 & 32,8 & 89 & 50,6 \\
\hline $\begin{array}{l}\text { Decyzje najważniejsze dla działalności spółdzielni podejmowali } \\
\text { wszyscy członkowie, a codzienne zarządzanie było w gestii zarządu }\end{array}$ & 26 & 23,2 & 14 & 21,9 & 40 & 22,7 \\
\hline $\begin{array}{l}\text { Zarządzaniem zajmował się zarząd, a rolą członków było tylko } \\
\text { wybieranie i rozlicznie zarządu, gdy upływała kadencja }\end{array}$ & 14 & 12,5 & 1 & 1,6 & 15 & 8,5 \\
\hline Respondenci nie mieli wpływu na zarządzanie spółdzielnią & 4 & 3,6 & 28 & 43,8 & 32 & 18,2 \\
\hline 0GółEM & 112 & 100,0 & 64 & 100,0 & 176 & 100,0 \\
\hline
\end{tabular}

Źródło: [Sobczak, 2016a, s. 121].

Praktycznie każdy z badanych założycieli miał okazję w jakimś stopniu współzarządzać spółdzielnią socjalną, a 60\% z nich brało udział przy podejmowaniu większości decyzji w organizacji. W przypadku pracowników większość miała okazję współuczestniczyć w zarządzaniu, jednak ponad $40 \%$ z nich nie miała żadnego wpływu na zarządzanie organizacją. Oznacza to, że rozwój kompetencji menedżerskich i przedsiębiorczych był niewątpliwie ograniczony wśród pracowników. Różnice między badanymi grupami uwidaczniały się również w charakterze pracy wykonywanej w spółdzielni socjalnej (tabela 5). 
Tabela 5. Charakter pracy wykonywanej w spółdzielni socjalnej wg pracowników najemnych i założycieli

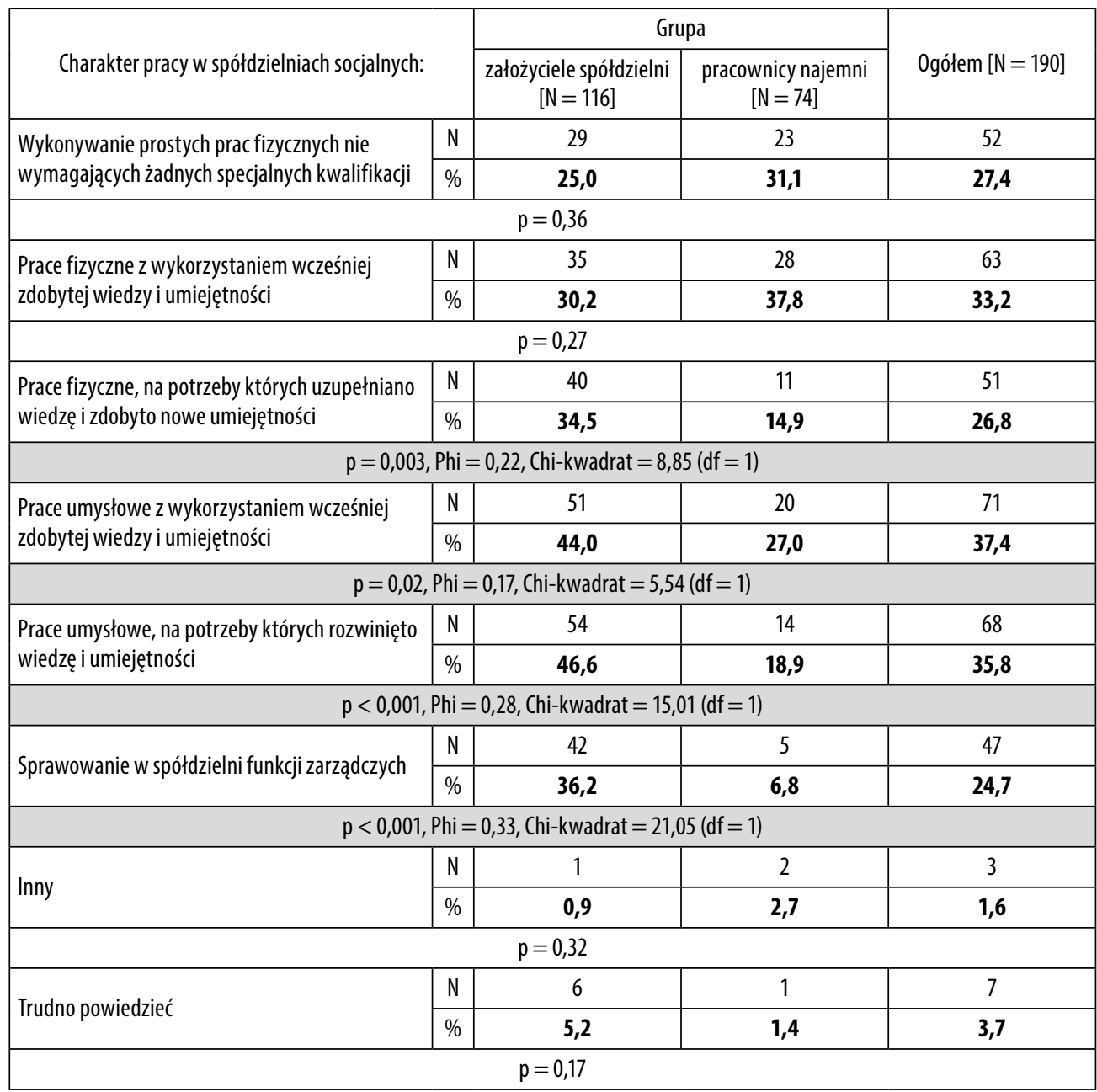

Źródło: [Sobczak, 2016a, s. 122].

Powyższe dane obrazują dużo większą wszechstronność założycieli, którzy wykonują w spółdzielniach wszelkie prace - od prostych fizycznych po specjalistyczne umysłowe oraz związane z kierowaniem organizacją. W przypadku prac fizycznych wymagających uzupełniania wiedzy i umiejętności, wszelkich prac umysłowych i zarządczych, testowanie statystyczne wykazało istotną różnicę w częstotliwości wyboru tych odpowiedzi pomię- dzy grupami. Pracownicy nieco częściej byli kierowani do wszelkiego typu prac fizycznych (choć różnica nie była istotna statystycznie), czasem umysłowych. Tym samym, odpowiadać temu też będzie profil kompetencyjny osoby po przejściu procesu reintegracji zawodowej w spółdzielni socjalnej.

Spółdzielnie socjalne mają też wpływ na kontakty społeczne swoich członków lub pracowników. Większość respondentów (54,2\%) 
rozwinęła kontakty społeczne i zdobyła nowe grono znajomych. Żadnych większych zmian w zakresie kontaktów z otoczeniem nie zauważyło u siebie ponad $40 \%$ pracowników oraz przeszło $23 \%$ założycieli. Jednocześnie założyciele częściej niż pracownicy odpowiadali, że praca w spółdzielni socjalnej przyczyniła się do ograniczenia kontaktów z rodziną (odpowiednio: 22,4\% oraz 9,5\%) i znajomymi (20,7\% oraz 5,4\%). Z przeprowadzonych rozmów ze spółdzielcami wynikało, że miało to związek z natłokiem pracy w spółdzielni socjalnej.

Ostatnią z kategorii, w których uwidoczniły się różnice pomiędzy grupami, było hipotetyczne zachowanie spółdzielców w sytuacji, w której upada spółdzielnia socjalna. Założyciele byli raczej pewni swoich kwalifikacji i zdobycia nowej pracy (50\%) lub deklarowali chęć założenia działalności gospodarczej (20\%). U pracowników najczęściej udzielaną odpowiedzią była utrata reszty nadziei na jakąkolwiek możliwość poprawy sytuacji życiowej (24\%). Przy okazji mniej więcej 1/5 respondentów w obu grupach nie potrafiła odpowiedzieć na to pytanie.

\section{Podsumowanie}

Przeprowadzone badania potwierdziły założenie, że w spółdzielniach socjalnych funkcjonują dwa typy spółdzielców o dość różnej charakterystyce. Założyciele to zazwyczaj osoby młode, dobrze wykształcone, przedsiębiorcze oraz pełne zapału do pracy. Spółdzielnia socjalna to dla nich szansa na spełnienie marzeń i spróbowanie sił w działalności gospodarczej. W razie upadku organizacji byli raczej pewni swojego przygotowania do powrotu na otwarty rynek pracy lub założenia własnego biznesu. Pracownicy byli grupą ze zdecydowanie większymi problemami życiowymi. To często osoby słabo wykształcone, o niewielkich możliwościach odnalezienia się na otwartym rynku pracy. Dzięki spółdzielni pracowali, co powodowało poprawę ich sytuacji materialnej. Innych korzyści raczej sami nie dostrzegali. Pracując nabywali jednak cenne kompetencje, które w razie konieczności zmiany pracy mogliby wykorzystać u nowego pracodawcy.

Realizowany przy okazji proces reintegracji społeczno-zawodowej przebiegał trochę lepiej w grupie założycieli, którzy na wstępie byli mniej oddaleni od otwartego rynku pracy. Spółdzielczość socjalna to dla nich jeden ze sposobów na życie, okazja na spełnienie marzeń o własnym biznesie. Spółdzielczość socjalna była dla nich szansą na usamodzielnienie się, wzięcie we własne ręce odpowiedzialności za swoje życie i pracę. Przez to nawet w sytuacjach, gdy czasami wykonywali proste prace fizyczne, zyskiwali też poczucie sprawstwa w organizacji. Mieli również szansę rozwinąć szereg kompetencji związanych z prowadzeniem biznesu czy pracą w zespole. Założyciele zdecydowanie więcej czasu poświęcali na pracę, niż to wynikało z formalnych uregulowań, co miało związek z ich poczuciem odpowiedzialności za przedsięwzięcie. Na badanym etapie rozwoju organizacji, założyciele raczej nie uzyskiwali większych korzyści ekonomicznych wynikających z pracy, ale też ich oczekiwania były odmienne. Chcieli głównie rozwinąć się zawodowo, a spółdzielnia stwarzała taką sposobność, rozwijając przy okazji jeszcze ich kompetencje społeczne i psychologiczne. Dzięki pracy w spółdzielniach nawiązywali wiele nowych kontaktów międzyludzkich, choć czasem nawał pracy ograniczał intensywność kontaktów towarzyskich czy rodzinnych. W większości traktowali spółdzielnię jako trwałe miejsce pracy, jednak w razie upadku organizacji byli raczej spokojni o powodzenie swojej dalszej kariery zawodowej.

Wśród pracowników najemnych reintegracja zawodowa związana była głównie z zapewnieniem bezpieczeństwa ekonomicznego oraz pewnością zatrudnienia. Pracownicy $w$ momencie przystąpienia do 
spółdzielni liczyli w pierwszej kolejności na korzyści ekonomiczne. Korzyści natury zawodowej, społecznej czy psychologicznej były swoistym pozytywnym skutkiem ubocznym. Dzięki pracy w spółdzielniach nastąpiła u nich również poprawa kontaktów społecznych, w tym rodzinnych. Najczęściej traktowali spółdzielnie jako stałe miejsce

\section{Literatura}

Brzozowska J. (2011). „Usługi społeczne świadczone przez spółdzielnie socjalne", w: M. Grewiński, M. Rymsza (red.), Polityka aktywizacji w Polsce. Usługi reintegracji w sektorze gospodarki społecznej (s. 218-233). Warszawa: Wydawnictwo WSP TWP w Warszawie.

Kliombka-Jarzyna J. (2009). "Psychospołeczne aspekty funkcjonowania spółdzielni socjalnych", w: Z. Janowska (red.), Spółdzielczość socjalna droga do aktywności zawodowej i przeciwdziałania wykluczeniu społecznemu. Łódź: Międzynarodowa Fundacja Kobiet.

Koperek J., Koperek A. (2015). „Zasady funkcjonowania spółdzielni socjalnych w Polsce (na podstawie Ustawy o spółdzielniach socjalnych)", w: W. Janocha, J. Koperek, K. Zielińska-Król (red.), Spółdzielnie socjalne jako instrument polityki społecznej państwa (s. 9-28). Lublin: Wydawnictwo KUL.

Koral J. (2008). Podmioty ekonomii społecznej. Spółdzielnie socjalne. Warszawa: Fundacja Inicjatyw Społeczno-Ekonomicznych.

Łukasiewicz A. (2016). „Profilowanie bezrobotnych problemy i wyzwania", Kwartalnik KES Studia i Prace, 1 (25), s. 217-237.

Schmid G. (1998). "Transitional labour markets: A new European employment strategy", WZB Discussion Paper, FS I 98-206. pracy i nie przewidywali możliwości dobrowolnego odejścia z organizacji. W przypadku bankructwa spółdzielni istniało spore ryzyko, że wielu pracowników najemnych może utracić nadzieję na jakąkolwiek poprawę swojej sytuacji życiowej, co mogłoby doprowadzić do pogłębienia ich wykluczenia.

Sobczak M. (2015). „Reintegracja społeczno-zawodowa osób po 45 roku życia w spółdzielniach socjalnych", Acta Universitatis Lodziensis. Folia Oeconomica, 2 (312), s. 173-194.

Sobczak M. (2016a). Reintegracja zawodowa w spółdzielniach socjalnych na przykładzie województwa łódzkiego. Łódź: Wydawnictwo Uniwersytetu Łódzkiego.

Sobczak M. (2016b). Wykluczenie społeczne $i$ inkluzja społeczna z wykorzystaniem podmiotów ekonomii społecznej w Polsce na przykładzie województwa łódzkiego. Łódź: Wydawnictwo Uniwersytetu Łódzkiego.

Sobol A. (2009). Społeczne aspekty działalności spółdzielni socjalnych. Warszawa: Ogólnopolski Związek Rewizyjny Spółdzielni Socjalnych oraz Krajowa Rada Spółdzielcza.

Szczygieł E. (2014). "Spółdzielnie socjalne jako odpowiedź na wybrane problemy społeczne. Przykład województwa podkarpackiego", Ekonomia Spoteczna, nr 2, s. 36-47.

Wojdyło-Preisner M. (2009). Profilowanie bezrobotnych jako metoda przeciwdziałania długookresowemu bezrobociu. Toruń: WNUMK.

Ustawa z dnia 20 kwietnia 2004 roku o promocji zatrudnienia i instytucjach rynku pracy (Dz.U. 2004 nr 99 poz. 1001 z późn. zm).

Ustawa z dnia 27 kwietnia 2006 roku o spółdzielniach socjalnych (Dz.U. 2006 nr 94 poz. 651 z późn. zm).

\section{Two worlds of social cooperatives in Poland}

Summary: Social co-operatives are one of the social policy's tools that aims to counteract social exclusion. Depending on the distance from the open labor market it might be implemented in two ways, i.e. the path of founders or employees. The aim of the paper is to present the characteristics of two types of social cooperative stakeholders, i.e. founders and employees. Special attention will also be paid to the differences in the way social co-operatives implement occupational reintegration for both types of stakeholders together with an analysis of the chances of success of this process. The discussion in this paper was based on the results of the survey of the author's own research on social co-operatives in the Lodz province. The research indicated that the founders are usually young, well-educated, entrepreneurial and energetic. Social co-operatives gave them a chance to fulfill their dreams and try their hand at business. Employees, on the other hand, are mostly poorly educated and have little chance of finding themselves in the open labor market. Thanks to the cooperatives they improve their financial situation and acquire valuable competences.

Keywords: social cooperative, social exclusion, social inclusion, labor market. 


\section{Prawa autorskie i licencja / Copyright and License}

Artykuł opublikowano na licencji Creative Commons

Uznanie autorstwa - Użycie niekomercyjne - Bez utworów zależnych 3.0 Polska

http://creativecommons.org/licenses/by-nc-nd/3.0/pl/

This article is published under the terms of the Creative Commons

Attribution - NonCommercial - NoDerivs (CC BY-NC-ND 3.0) License

http://creativecommons.org/licenses/by-nc-nd/3.0/ 